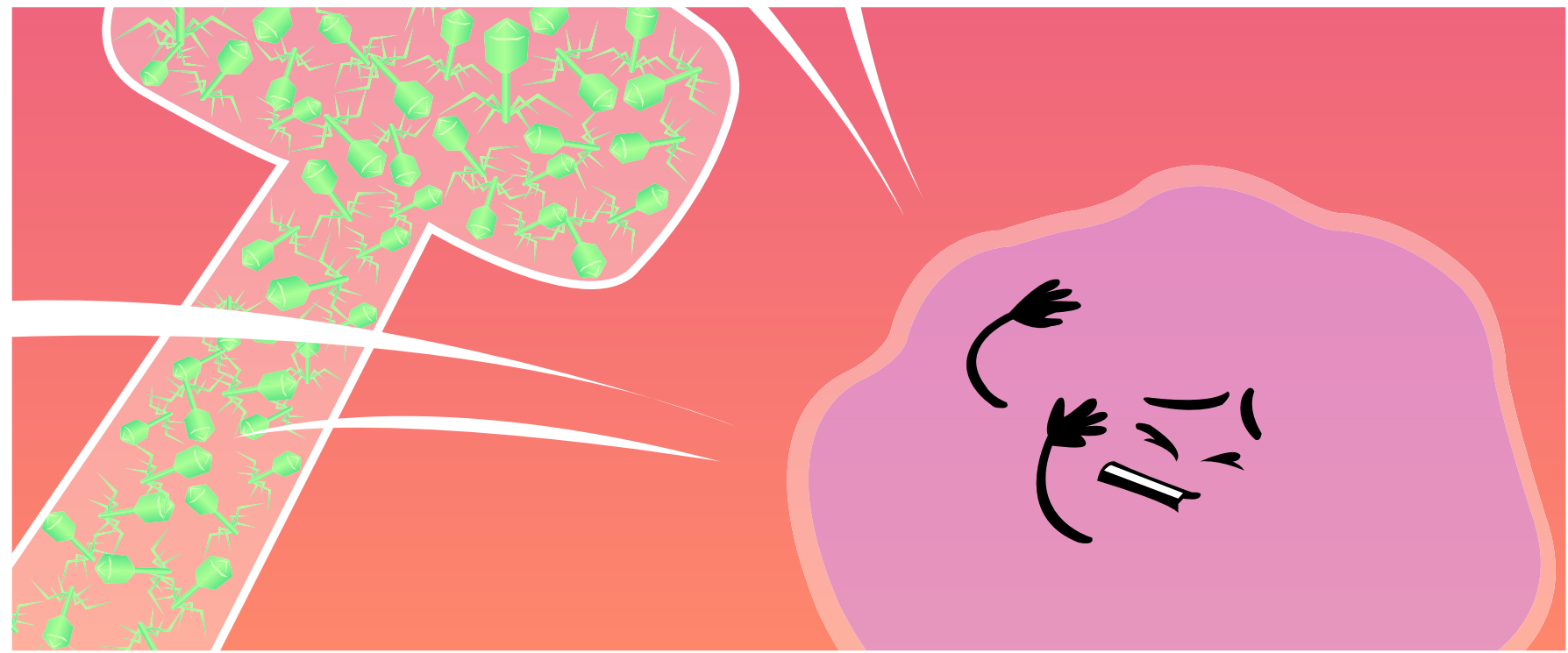

\title{
BACTERIOPHAGES: THE ENEMIES OF BAD BACTERIA ARE OUR FRIENDS!
}

\section{Diana Gutiérrez, Lucía Fernández, Beatriz Martínez, Ana Rodríguez and Pilar García*}

DairySafe Group, Instituto de Productos Lácteos de Asturias (IPLA), Consejo Superior de Investigaciones Científicas (CSIC), Villaviciosa, Spain

\section{REVIEWED BY: \\ ANJISHNU 9 YEARS OLD}

\section{BACTERIA}

Small microorganisms that can be beneficial or dangerous for people.

\section{PATHOGENIC}

Some microorganisms that cause disease.
Some bacteria can enter the human body and make people ill. Usually, these diseases can be cured by antibiotics, but sometimes bacteria are resistant to them, meaning that the antibiotics do not kill the bacteria. In these cases, bacteria become very dangerous. Bacteriophages are viruses that infect bacteria but are harmless to humans. To reproduce, they get into a bacterium, where they multiply, and finally they break the bacterial cell open to release the new viruses. Therefore, bacteriophages kill bacteria. Here, we explain how bacteriophages can be used to treat infectious diseases or to remove bacteria from other places where they are unwanted.

\section{SOME BACTERIA CAN BE VERY DANGEROUS}

Bacterial cells are so small that they can only be observed under a microscope. Some useful bacteria live in different parts of our bodies, where they are very important for our health. For instance, these good bacteria protect our skin from bad bacteria and good bacteria living in the gut also help to digest the food we eat every day! However, other bacteria are harmful to our health and are the cause of several diseases. These harmful bacteria are named "pathogenic bacteria." 


\section{ANTIBIOTICS}

Chemical compound able to kill bacteria.

\section{SUPERBUGS}

Bacteria resistant to several antibiotics.

\section{FIGURE 1}

Bad bacteria causing disease are named pathogenic bacteria. Bacterial diseases are treated with antibiotics and most of the bacteria died. Sometimes, one bacterium survives because it is resistant to the antibiotics. This bacterium is named "superbug." Antibiotics can not kill this bacterium, and it multiplies resulting in a lot of bacteria, all of them resistant to antibiotics.
When people get sick due to these bacteria, it is necessary to visit the doctor, who might prescribe antibiotics and even give you a painful shot! Antibiotics are chemical compounds that kill bacteria, helping us recover and feel better.

Antibiotics have been used for almost a century to treat bacterial diseases in humans and also in animals. Throughout this time, bacteria have been looking for strategies to survive antibiotic treatment [1]. Imagine a battlefield, where a population of bacteria is attacked by small bullets (antibiotics). If one of the bacteria can find a shield to protect itself, it will survive (Figure 1). The surviving bacteria will have the advantage of being resistant to antibiotics forever and so will their descendants. This is the reason why, when you get sick, you have to take all the pills prescribed by the doctor, even if you already feel better. This is very important to prevent "survivors" in the battle! Bacteria resistant to antibiotics (called "superbugs") are very dangerous for us, because we have no weapons to fight against them. Also, these resistant bacteria can be transmitted to other people or even to animals. Nowadays, there are a high number of bacteria that have become resistant to many different antibiotics, and this is a threat for people worldwide.

\section{HOW CAN WE FIGHT AGAINST ANTIBIOTIC-RESISTANT BACTERIA?}

The main way to prevent more and more bacteria from becoming resistant to antibiotics is to use the antibiotics properly. This means strictly following

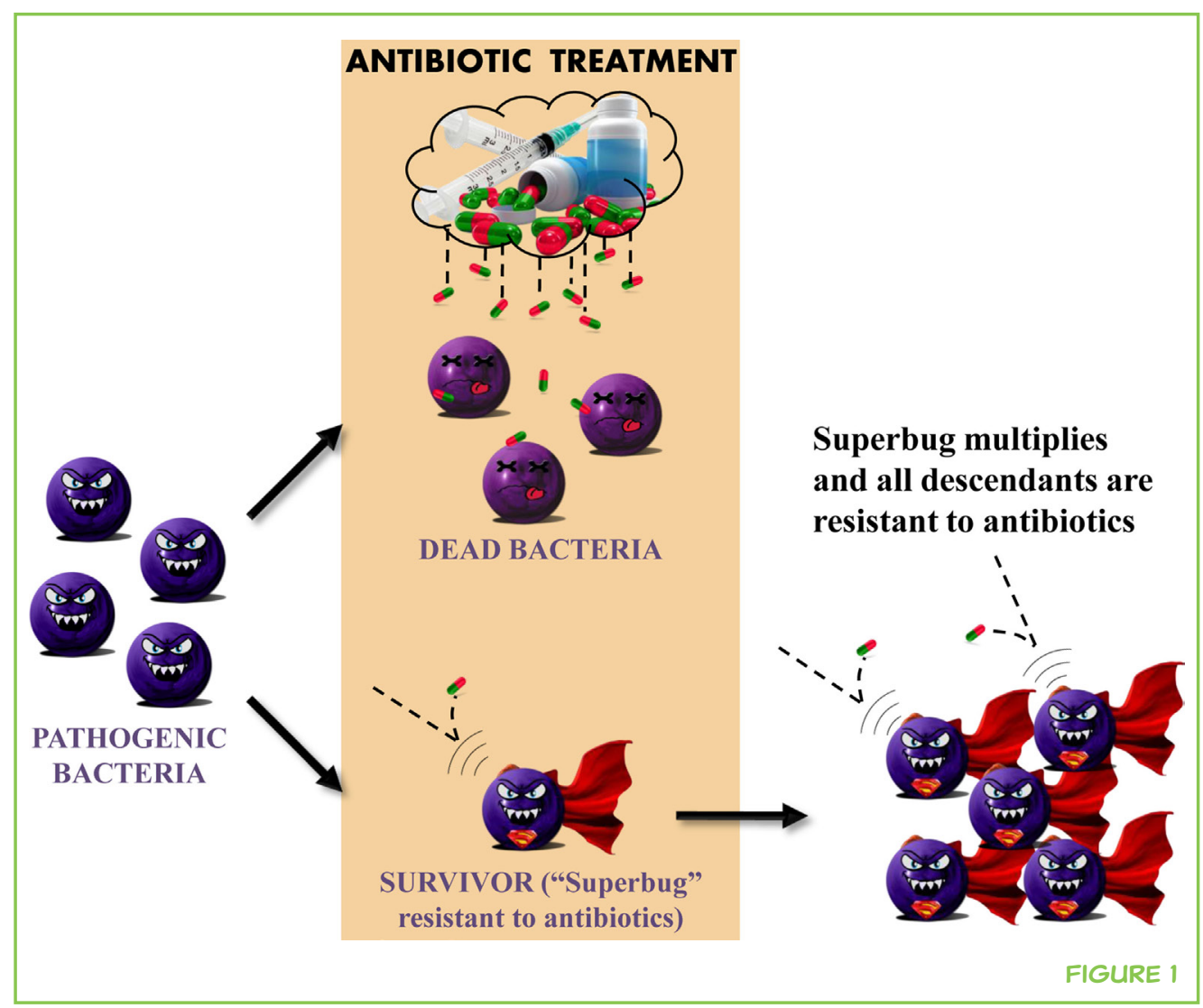




\section{BACTERIOPHAGES}

A type of virus that needs bacteria to reproduce.

\section{VIRUSES}

The most simple microorganism known.

\section{LYTIC CYCLE}

The process of reproduction of bacteriophages.

\section{ECOSYSTEMS}

A set of living things and the place where they live.

\section{FIGURE 2}

Image of several bacteriophages seen under a microscope. the doctor's recommendations. So, it is very important to take antibiotics only when it is necessary. We should never take these medicines without a doctor's prescription, as only the doctor knows when we actually need them. In addition to using antibiotics properly, it is essential to find new strategies to fight against bacteria, especially those bacteria that are resistant to many antibiotics. Fortunately, there are other microorganisms in nature that had already succeeded in killing bacteria: the bacteriophages.

\section{WHAT ARE BACTERIOPHAGES?}

Bacteriophages are one of the many types of viruses. Viruses are the most simply living thinks. When viruses infect animals, plants, or humans, they are called "eukaryotic viruses," and they are called "bacteriophages" when they infect bacteria. All viruses are very tiny microorganisms that can only be observed with a huge magnification by using a special microscope (Figure 2). Bacteriophages are very abundant; actually, there are thousands of millions of bacteriophages around us, although we cannot see them. They live everywhere: in the soil, in the oceans, in our bodies, and also in food (we eat bacteria and bacteriophages every day!). But we should not worry about bacteriophages because they are harmless to all of us and also to animals and plants. Bacteriophages are only dangerous for bacteria because they need bacteria to reproduce. The reproduction of bacteriophages is quite different from that of animals or plants. Their reproductive process, called the "lytic cycle," happens very quickly; for some bacteriophages, it only takes $30 \mathrm{~min}$ ! If we were able to stop the process and see what is happening inside the cell, we would observe three different steps (Figure 3 ). At the end of the lytic cycle, the bacterium dies. Bacteriophages are, therefore, the natural enemies of bacteria. In nature, both bacteria and bacteriophages are necessary to keep microscopic ecosystems working properly. This is similar to what occurs with animals, when the predator (fox) and the prey (hare) live together in the same place, despite being enemies.

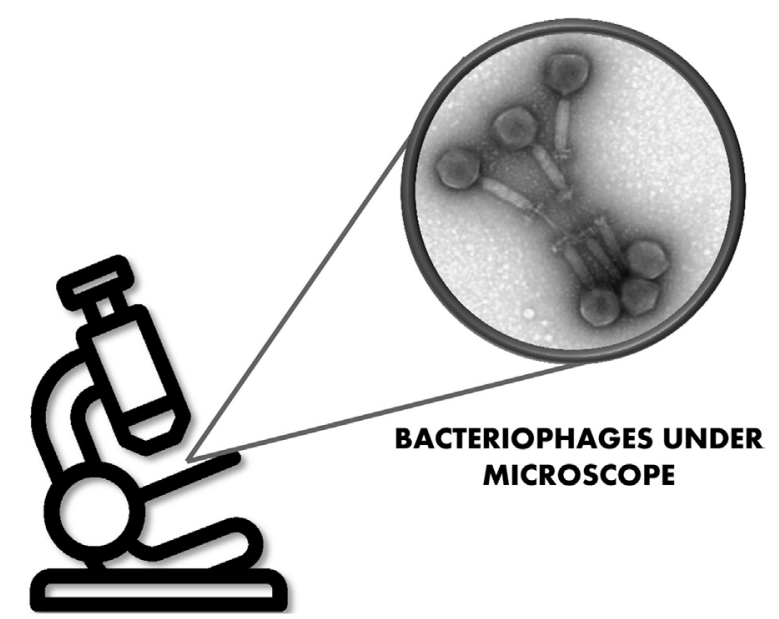

FIGURE 2 


\section{FIGURE 3}

How bacteriophages reproduce.

Step 1: a bacteriophage meets a bacterium and binds to it. Step 2: the genetic material of the bacteriophage enters the bacterium and replicates, thereby creating new bacteriophages. Step 3: the bacterium is full of bacteriophages and explodes!

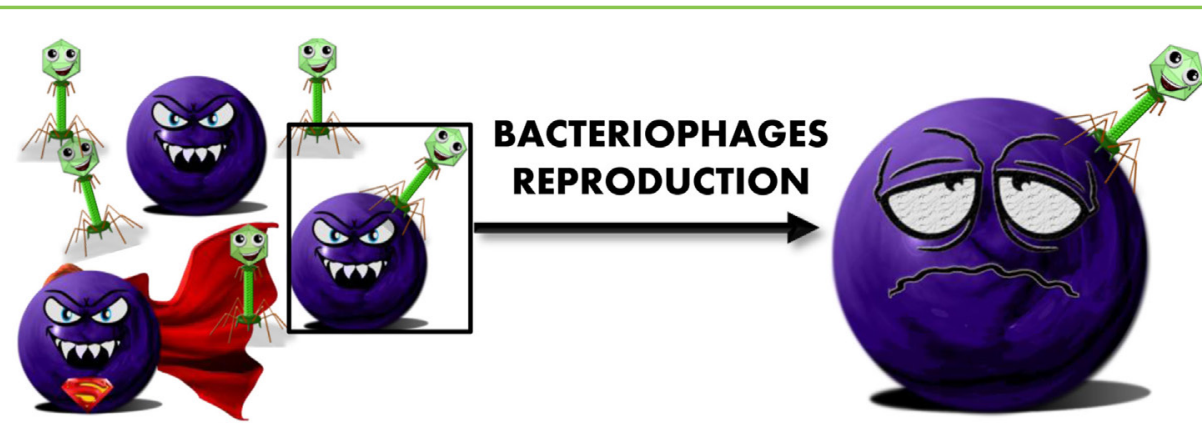

Bacteria and bacteriophages live together in Nature

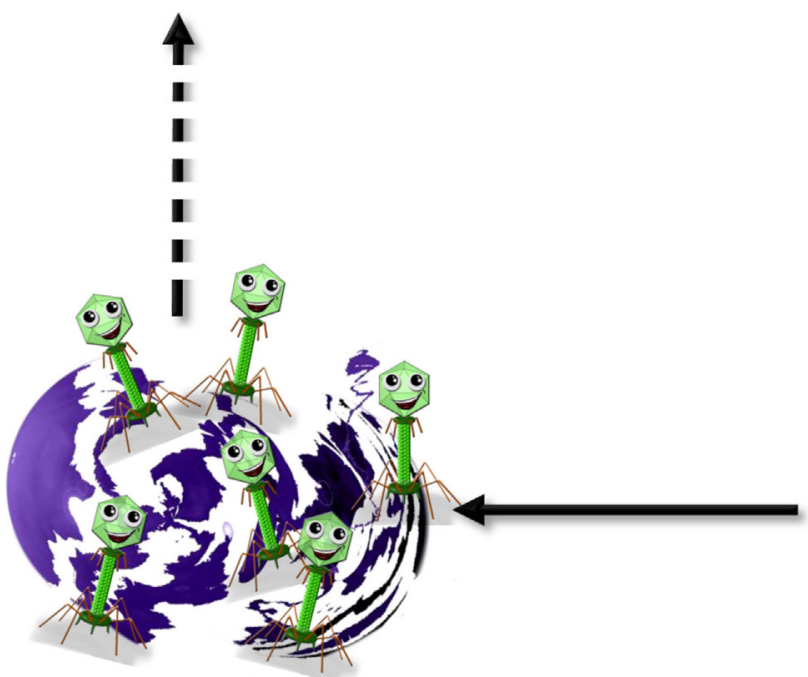

3) Bacterium explodes.

New bacteriophages can

) Bacteriophage binds to the bacterium

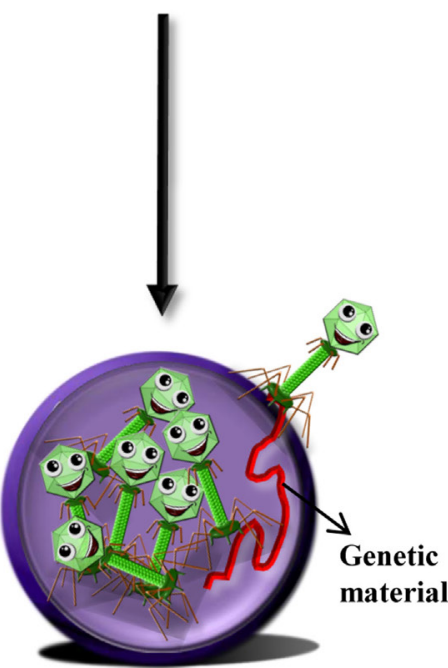

2) Bacteriophages multiply inside the bacterium

\section{ARE BACTERIOPHAGES USEFUL FOR US?}

Yes, they are. We can use bacteriophages to kill bad bacteria in a way that is similar to the way we use antibiotics [2]. Moreover, bacteriophages have some advantages compared with antibiotics. For instance, antibiotics usually kill different types (species) of bacteria, while bacteriophages generally attack only one kind of bacteria. As a result, bacteriophages that kill bad bacteria do not affect beneficial bacteria, and most of the time we do not want to exterminate all the bacteria, only the "bad guys." Of course, before we can give people bacteriophages as medicines, the bacteriophages should be studied to be sure that they are totally safe. Actually, a great number of scientists working on this research area have found other uses for bacteriophages. For example, bacteriophages can be used to clean hospitals or industrial surfaces, since they can destroy undesirable bacteria like disinfectants do. It is also possible include bacteriophages in foods, which will work similar to chemical preservatives [3]. Bacteriophages will wait in the food until some bad bacteria contaminate it and, like playing hide-and-seek, when the bacteriophages find their bacterial targets, they 
will catch them! Do you now believe that bacteriophages are good weapons to combat bad bacteria?

\section{AUTHOR CONTRIBUTIONS}

DG, LF, BM, AR, and PG contributed to writing. DG designed the figures.

\section{REFERENCES}

1. Nikaido, H. 2009. Multidrug resistance in bacteria. Annu. Rev. Biochem. 78:119-46. doi:10.1146/annurev.biochem.78.082907.145923

2. Kutter, E., De Vos, D., Gvasalia, G., Alavidze, Z., Gogokhia, L., Kuhl, S., et al. 2010. Phage therapy in clinical practice: treatment of human infections. Curr. Pharm. Biotechnol. 11:69-86. doi:10.2174/138920110790725401

3. García, P., Martínez, B., Obeso, J. M., and Rodríguez, A. 2008. Bacteriophages and their application on food safety. Lett. Appl. Microbiol. 47:479-85. doi:10.1111/j.1472-765X.2008.02458.x

SUBMITTED: 09 November 2015; ACCEPTED: 06 December 2016; PUBLISHED ONLINE: 23 December 2016.

EDITED BY: Pasquale Maffia, University of Glasgow, UK

CITATION: Gutiérrez D, Fernández L, Martínez B, Rodriguez A and García P (2016) Bacteriophages: The Enemies of Bad Bacteria are our Friends! Front. Young Minds 4:30. doi:10.3389/frym.2016.00030

CONFLICT OF INTEREST STATEMENT: The authors declare that the research was conducted in the absence of any commercial or financial relationships that could be construed as a potential conflict of interest.

COPYRIGHT @ 2016 Gutiérrez, Fernández, Martínez, Rodriguez and García. This is an open-access article distributed under the terms of the Creative Commons Attribution License (CC BY). The use, distribution and reproduction in other forums is permitted, provided the original author(s) or licensor are credited and that the original publication in this journal is cited, in accordance with accepted academic practice. No use, distribution or reproduction is permitted which does not comply with these terms.

\section{REVIEWED BY}

\section{ANJISHNU, 9 YEARS OLD}

Hello, my name is Anjishnu, and I am in fourth grade. I live in San Diego, and I have a passion in writing, reading, math, and science. I also like reading about cars and other vehicles. I enjoy playing tennis and guitar. I want to be an inventor when I grow up and would like to invent things that will make us healthier and our world safer. Also, I am trying to figure out how time travel could be possible. 

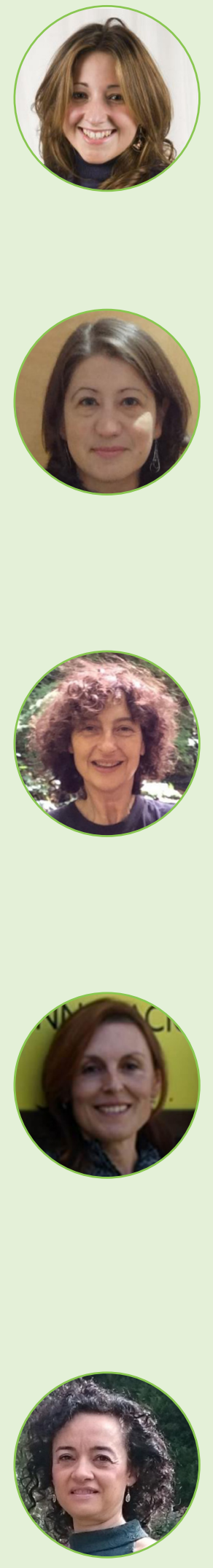

\section{AUTHORS}

\section{DIANA GUTIÉRREZ}

I am a microbiologist and, as a young researcher, I have been introduced to the magical world of bacteriophages just a few years ago. Since I was studying my Degree in Biological Sciences, I have always wanted to fight against pathogenic bacteria. I reached my dream when I started my Ph.D. using small viruses that kill bacteria. Now, as a more consolidated scientist, I continue my research in the use of bacteriophages as antimicrobials to combat pathogenic bacteria that represent a serious threat for human health.

\section{LUCÍA FERNÁNDEZ}

Since as far as I can remember, I have wanted to understand "how Nature works." Because of my love for animals, I originally wanted to be a zoologist, but during my undergraduate studies, I became increasingly interested in much much much smaller creatures. As a microbiologist, I have tried to "decipher" how pathogenic bacteria cause disease and, more importantly, how we can get rid of them. My current work focuses on understanding the interplay between bacteria and bacteriophages, so we can use these small viruses to eliminate "bad bugs" without harming ourselves or the environment.

\section{BEATRIZ MARTINEZZ}

I am a microbiologist interested on harnessing natural antimicrobial compounds to kill harmful bacteria in food. In nature, many bacteria have evolved different strategies to outcompete others such as the production of bacteriocins. Understanding how these small but extremely potent antimicrobial peptides work has always been the main focus of my research career. Recently, we notice that bacteriocins may be combined with other natural "barriers" such as bacteriophages, providing us with new means to enhance food safety in a sustainable way.

\section{ANA RODRIGUEZ}

I started to work on bacteriophages during my Ph.D. By that time, it was very important the development of cloning vectors based on bacteriophages for Streptomyces, an antibioticproducing bacterium. Afterward, I focused my research on bacteriophages infecting bacteria responsible for the manufacture of fermented foods (cheese, yoghurt, etc.). In this case, my purpose was to avoid the infection of these beneficial bacteria by bacteriophages as these cause failures in food fermentations. More recently, I started to study the bacteriophages as weapons to fight against antibiotic-resistant bacteria that cause infections in humans and animals.

\section{PILAR GARCIA}

I am a microbiologist who discovered the "bacteriophage world" some time ago, at the beginning of my postgraduate studies, and since then, I have been fascinated by these tiny and intelligent creatures. Throughout my research career, I have had the opportunity to study bacteriophages that kill beneficial and undesirable bacteria. At present, I am interested in taking advantage of the mechanisms that bacteriophages have acquired through millions of years of evolution, to construct weapons to fight against bacteria resistant to antibiotics. *pgarcia@ipla.csic.es 